\title{
USING THE DEPLETED FRACTION TO MANAGE THE GROUNDWATER TABLE IN IRRIGATED AREAS $[1]$
}

\author{
Marinus G. Bos $[2]$ and Wim G.M. Bastiaanssen[3]
}

\begin{abstract}
The depleted fraction, defined as the ratio of $E T_{\text {actual }}$ over $\left(P+V_{C}\right)$, relates parameters of the water balance of an irrigated area with each other in such a way that the (water) manager obtains information on the rate of change of water stored in the area (soil moisture and groundwater). If the depleted fraction equals about 0.6 water storage in the area is stable, while water is stored for lower values of the depleted fraction.

If the value of the depleted fraction exceeds 0.6 , the volume of water stored in the area decreases. Part of this decrease is due to natural drainage and part due to capillary rise into the root zone of the irrigated crop. Despite this capillary rise the actual evapotranspiration drops below the potential $E T$-value. For most crops, a decrease of $E T$ by about $15 \%$ would result to a higher productivity in terms of yield per cubic meter water. However, the yield per hectare (and thus farm income) would decrease.

Management of an irrigation system is recommended in such a way that the monthly values of the depleted fraction range between 0.5 and 0.8. Such a management rule would provide sufficient water for leaching (at the 0.5 side of the range) and provide high crop yield per unit water consumed (at the 0.8 side).
\end{abstract}

Keywords: Groundwater, management, irrigation, semi-arid regions, drainage

\section{$1 \quad$ INTRODUCTION}

The diversion of irrigation water into an arid or semi-arid area in order to grow an agricultural crop is a human intervention in the local environment. The primary intended (positive) effect is a higher crop yield; the most common unintended (negative) effect is a rising groundwater table. This rising groundwater table in turn may cause water logging and soil salinity within the irrigated area and an increased drainage flow into the downstream environment. This drainage water usually transports a variety of chemicals (salts, pesticides, etc.).

The schematic water balance of an irrigated area (Figure 1) shows three inflows of water: precipitation $(P)$, groundwater flow from upstream $\left(G_{i n}\right)$ and river diversion $\left(V_{c}\right)$. Of these, the groundwater inflow is often the same order of magnitude as the groundwater outflow. Part of the river diversion plus precipitation $\left(P+V_{C}\right)$ is actually evapo-transpirated ( $\left.E T_{\text {actual }}\right)$ to produce a crop (the above positive effect), the remaining part is either stored within the irrigated area or drained (the above negative effects). The ratio of $E T_{\text {actual }}$ over $\left(P+V_{C}\right)$ thus can be used as an indicator to assess irrigation water use.

\section{THE DEPLETED FRACTION}

The depleted fraction is ratio that compares three components of the water balance of an (irrigated) area (Figure 1). It relates the actual evapo-transpiration from the area to the sum of all precipitation on this area plus the surface water inflow (irrigation water) into the area. It is defined as (Molden 1997: Bastiaanssen et al 2001): 


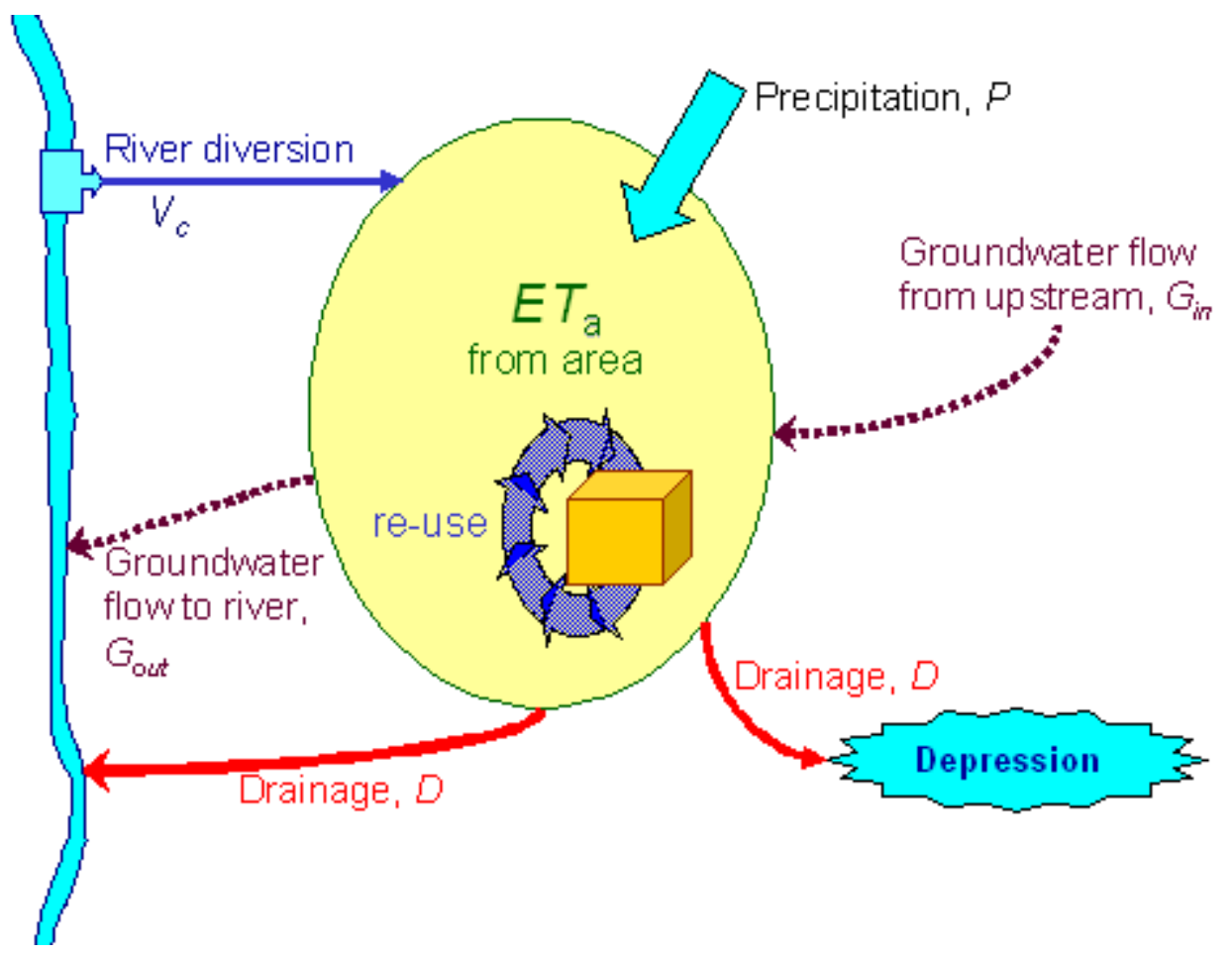

Figure 1 Schematic water balance of an irrigable area.

Depleted Fraction $=\frac{E T_{\text {actual }}}{P+V_{\mathrm{c}}}$

Because it is not practical to measure the $E T_{\text {actual }}$ and the precipitation for only the irrigated part of the area, we consider the gross command area. As shown in Figure 1, the depleted fraction quantifies the surface water balance excluding the drainage component. The water manager can influence the value of $V_{c}$ while this in turn influences the water deficit ( $\left.E T_{\text {potential }}-E T_{\text {actual }}\right)$ in the area.

Due to the above definition of the components of the water balance, the depleted fraction usually is quantified for the entire irrigated area. It is recommended to study the temporal variation of the depleted fraction for a time step that is long with respect to (natural) fluctuations in the above parameters. Thus, studies on a monthly basis are recommended to avoid ripples on the data due to rain showers and short canal closures (Bastiaanssen et al 2001).

At first glance, the depleted fraction looks alike the overall consumed ratio. The latter ratio (efficiency) quantifies the degree to which the crop irrigation requirements are met by irrigation water in the irrigated area (Bos and Nugteren 1974). Assuming negligible non-irrigation water deliveries to the area, the ratio is defined as:

Overall Consumed Ratio $=\frac{E T_{\text {potential }}-P_{e}}{V_{c}}$

Where $E T_{\text {potential }}$ is the potential evapotranspiration from the irrigated area and $P_{e}$ is the effective precipitation (USDA 1970; Bos et al 1996). The numerator of this ratio thus contains (ICID 1978): "the volume of irrigation water needed, and made available, to avoid undesirable stress in the crops throughout (considered part of) the growing cycle". The overall consumed ratio thus relates the crop irrigation water requirements $\left(E T_{\text {potential }}-P_{e}\right)$ for the irrigated area with the actual irrigation water supply $\left(V_{c}\right)$ to this area. It is an operational indicator that informs the irrigation manager on the adequacy of water supply to the actually irrigated area. The depleted fraction quantifies the water balance of the gross irrigable area.

\subsection{Three Examples}

Since several decades applied research is done to facilitate the more efficient use of irrigation water and to reduce the negative effects of water logging and salinity (Bos and Nugteren 1974). Since then, several case studies were published containing data on water use and recommendations to improve this water use. Data to quantify the depleted fraction are accessible for three previously studied irrigated areas. Some information on the case studies is summarized in Table 1. 
Table 1 Information on selected case studies.

\begin{tabular}{|l|l|l|l|}
\hline Project & $\begin{array}{l}\text { Fayoum depression, } \\
\text { Egypt }\end{array}$ & $\begin{array}{l}\text { Viejo Retamo lateral unit, } \\
\text { Argentina }\end{array}$ & $\begin{array}{l}\text { Nilo Coelho project, } \\
\text { Brazil }\end{array}$ \\
\hline Reference & Wolters et al 1989 & Bos et al 1991 & $\begin{array}{l}\text { Bastiaanssen et al } \\
2001\end{array}$ \\
\hline Gross area, ha & 150,000 & 4,890 & 33,800 \\
\hline Major soil type & clay & sandy loam & sandy loam \\
\hline $\begin{array}{l}\text { Annual precipitation, } \\
\text { mm/year }\end{array}$ & 10 & 234 & 586 \\
\hline Potential $E T, \mathrm{~mm} /$ year & 1950 & 1340 & 1560 \\
\hline $\begin{array}{l}\text { Method by which } V_{c} \text { is } \\
\text { measured }\end{array}$ & $\begin{array}{l}\text { calibrated inlet } \\
\text { structures at Lahun }\end{array}$ & $\begin{array}{l}\text { broad-crested weir at head } \\
\text { of canal }\end{array}$ & $\begin{array}{l}\text { Rating of pumping } \\
\text { station at head of } \\
\text { canal }\end{array}$ \\
\hline $\begin{array}{l}\text { Method by which } \\
E T_{\text {actual is determined }}\end{array}$ & $\begin{array}{l}\text { rest term in water } \\
\text { balance }\end{array}$ & rest term in water balance & $\begin{array}{l}\text { energy balance of } \\
\text { satellite image pixels }\end{array}$ \\
\hline
\end{tabular}

As mentioned above, the part of the water within the irrigated area that is not evapo-transpired either goes into storage or has to drain from the area. The volume of water that goes into storage (as soil moisture or groundwater) changes as a function of the other components of the water balance and as a function of the discharge capacity of the (natural) drainage system. For the three case studies (Table 1) monthly values of the depleted fraction were plotted against the rate of change of the groundwater table (sandy loamy soils) and against the change of moisture in the soil (clay soils). In all three areas the groundwater depth fluctuated around 2.0m. As shown in Figure 2, the regression line intersects the $\mathrm{x}$-axis near the 0.6 value of the depleted fraction.

\section{DISCUSSION}

Comparing the three case studies of Figure 2 shows that the value of the depleted fraction influences the volume of water stored within the irrigated area. The intersection points of the three regression curves averages around

$$
\frac{\mathrm{ET}_{\text {actual }}}{\mathrm{P}+\mathrm{V}_{\mathrm{o}}} \approx 0.6
$$

In other words: if $E T_{\text {actual }}$ is less than about $0.6\left(P+V_{c}\right)$ a portion of this available water goes into storage causing the groundwater table to rise while storage decreases if $E T_{\text {actual }}$ is greater than $0.6\left(P+V_{C}\right)$. Apparently, the natural drainage in the three arid and semi-arid areas has a capacity that is sufficient to discharge about $0.4\left(P+V_{C}\right)$. Thus, the depleted fraction can be used as a performance indicator on irrigation water use. The volume of water diverted into the irrigated area can be reduced during months with a low depleted fraction. If this non-diverted water remains in a storage reservoir, which often is the case in arid and semi-arid regions, this water can be diverted during months.
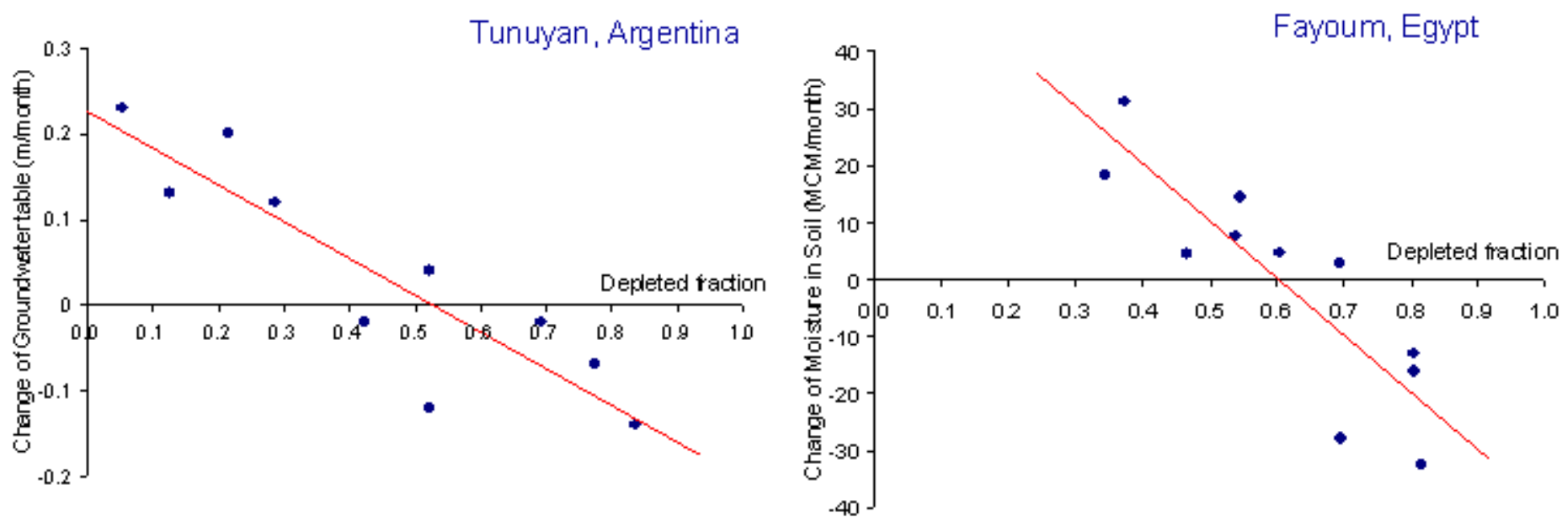


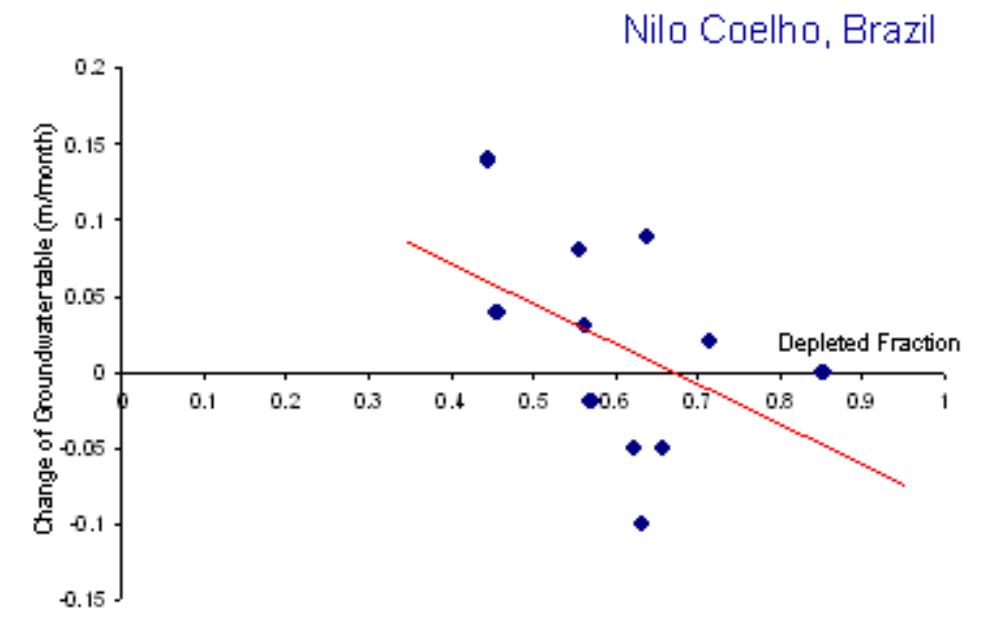

Figure 2 The rate of change of the groundwater table (or volume of moisture in the soil) as a function of the depleted ration of three irrigated areas.

The parameters $V_{c}$ and $E T_{\text {actual }}$ are not entirely independent of each other. As long as there is sufficient irrigation water, the $E T_{\text {actual }}$ will be near its potential value. However, $V_{c}$ is reduced in order to increase the depleted fraction, less water will be available for irrigation and $E T_{\text {actual }}$ will decrease. This impact of $V_{c}$ on $E T_{\text {actual }}$ is illustrated in Figure 3 for the Fayoum depression, Egypt. As shown, the evaporative fraction, $E T_{\text {actual }} / E T_{\text {potential }}$ remains about unity if the depleted fraction is less than 0.6 . During part of the year such a high evaporative fraction is needed to leach accumulated salts, etc. from the root zone of the crop. For higher values the depleted fraction the value of $E T_{\text {actual }} / E T_{\text {potential }}$ decreases by 10 to 20 percent. Due to the shape of the yield versus $E T$ curve of most crops, a decrease within this range results to a higher yield per cubic meter water. However, crop yield per hectare will decrease. To sustain agriculture on the one hand (leaching of the root zone is needed) and to attain a high productivity in terms of yield per cubic meter of water on the other hand, the monthly values of the depleted fraction should range between 0.5 and 0.8 .

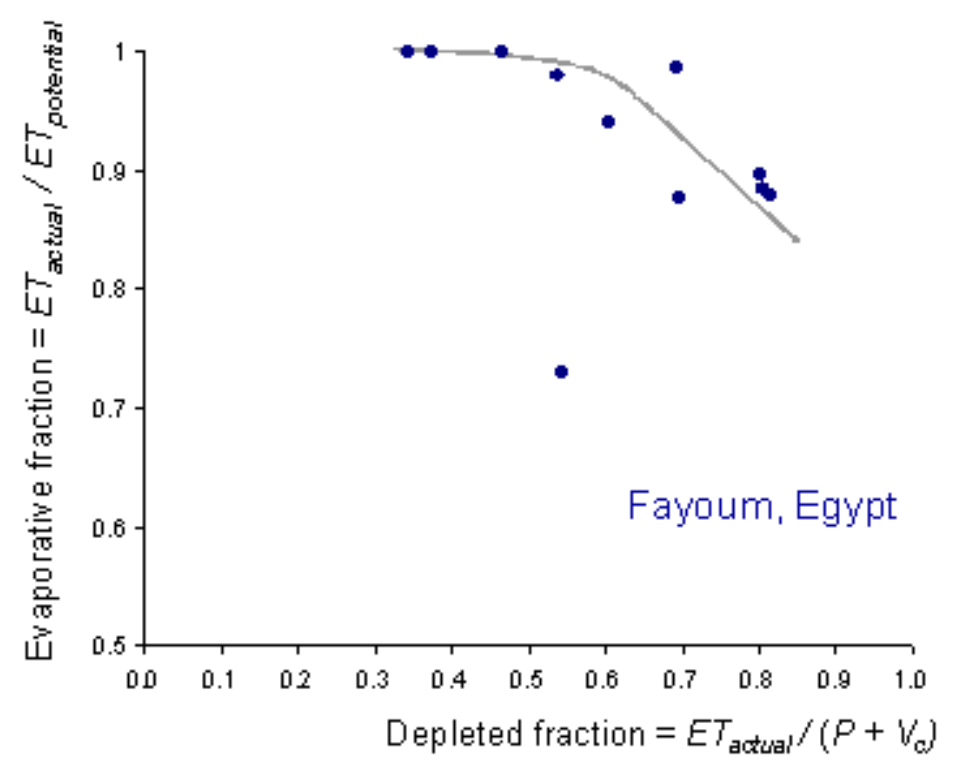

Figure 3 Influence of the depleted fraction on the avaporative fraction, Fayoum depression, Egypt.

The actual use of the depleted fraction as a performance indicator greatly depends on the method (and related cost) with which the parameters are quantified. Methods that provide sufficiently accurate data are summarized in Table 2 .

Table 2 Parameters and their method of measurement. 


\begin{tabular}{|c|c|}
\hline Parameter & Method by which term is measured or source of data \\
\hline $\begin{array}{l}\text { Actual evapo- } \\
\text { transpiration, } \\
E T_{\text {actual }}\end{array}$ & $\begin{array}{l}\text { The spatial variation of } E T_{\text {actual }} \text { can be calculated from the energy balance of the } \\
\text { pixels of a satellite image ( } 20 \% \text { error). Low resolution images (NOAA or MODIS) } \\
\text { are adequate to calculate monthly values. }\end{array}$ \\
\hline $\begin{array}{l}\text { Potential evapo- } \\
\text { transpiration, } \\
E T_{\text {potential }}\end{array}$ & $\begin{array}{l}\text { Potential ET can be calculated from a variety of equations. Most widely tested is } \\
\text { Penman-Monteith (error 20\%) (Bos et al 1996; Burt et al 2002) }\end{array}$ \\
\hline $\begin{array}{lrr}\text { Volume } & \text { of } & \text { water } \\
\text { diverted } & \text { from } \\
\text { river, } V_{c} & \end{array}$ & $\begin{array}{l}V_{c} \text { should be measured with a permanent flow measurement structure. If the } \\
\text { volume of water is calculated from } 15 \text { or more individual flow measurements } \\
\text { (readings) the error in the volume of water will be reduced to the systematic error } \\
\text { in these measurements (e.g. undershot gates } 5 \% \text {, broad-crested weirs } 2 \% \text { ). }\end{array}$ \\
\hline Precipitation, $P$ & $\begin{array}{l}\text { Precipitation is measured with a gage that is installed in accordance to } \\
\text { standardized rules (error 5\%). Data commonly are already available from local } \\
\text { meteorological stations. The spatial distribution of precipitation can be obtained } \\
\text { from weather satellite data (error 10\%). }\end{array}$ \\
\hline $\begin{array}{l}\text { Depth to } \\
\text { groundwater table }\end{array}$ & $\begin{array}{l}\text { The groundwater depth is measured by lowering a sounder or installing a } \\
\text { transducer into an observation well. The random error is about } 0.02 \mathrm{~m} \text {. A } \\
\text { systematic error of } 0.05 \mathrm{~m} \text { can occur in the reference elevation of the ground } \\
\text { surface. }\end{array}$ \\
\hline
\end{tabular}

\section{CONCLUSION}

The depleted fraction relates parameters of the water balance of an irrigated area with each other in such a way that the (water) manager obtains information on the rate of change of water stored in the area (soil moisture and groundwater). At a depleted fraction of about 0.6 storage is stable while water is stored for lower values of the depleted fraction.

If the value of the depleted fraction exceeds about 0.6 , the volume of stored water decreases. Part of this decrease is due to natural drainage and part due to capillary rise into the root zone of the irrigated crop. Despite this capillary rise the actual evapotranspiration drops below the potential $E T$-value. For most crops, a decrease of $E T$ by about $15 \%$ would result to a higher productivity in terms of yield per cubic meter water. However, the yield per hectare (and thus farm income) would decrease.

Management of an irrigation system in such a way that the monthly values of the depleted fraction range between 0.5 and 0.8 would provide sufficient water for leaching and provide high crop yield per unit water consumed.

\section{REFERENCES}

Bastiaanssen, W.G.M., R.A.L. Brito, M.G. Bos, R. Souza, E.B. Cavalcanti and M.M. Bakker 2001, Low cost satellite data applied to performance monitoring of the Nilo Coelho irrigation scheme, Brazil, Irrigation and Drainage Systems, Kluwer, Dordrecht, Vol. 15.1, pp 53-79.

Bos, M.G., and J. Nugteren. 1974. On Irrigation Efficiencies. Publication 19. 1st Edition 1974; 2nd Edition 1978; 3rd Revised Edition 1982; 4th Edition 1990. International Institute for Land Reclamation and Improvement/ILRI, Wageningen. pp. 117. 4th edition also published in Farsi with IRANCID, Tehran.

Bos, M.G., W. Wolters, A. Drovandi and J.A. Morabito. 1991. The Viejo Retamo secondary canal - Performance evaluation case study: Mendoza, Argentina. Irrigation and Drainage Systems 5:77-88.

Bos, M.G., J. Vos and R.A. Feddes. 1996. CRIWAR 2.0; A simulation model on crop irrigation water requirements, ILRI Publication 46. Wageningen: International Institute for Land Reclamation and Improvement. pp 117.

Burt, C.M., A.Mutziger, D.J.Howes and K.H.Solomon 2002, Evaporation from irrigated land in California, Irrigation Training and research center, Cal Poly, San Luis Obispo, ITCR Report R02-001, pp 166.

Molden, D.J., 1997. Accounting for water use and productivity, SWIM paper 1, International Water Management Institute (IWMI), Colombo, Sri Lanka: $16 \mathrm{pp}$.

USDA Soil Conservation Service 1970. Irrigation Water Requirements. Technical Release 21.

Wolters, W., Nadi Selim Ghobrial, H.M. van Leeuwen, and M.G. Bos. 1989. Managing the Water Balance of the Fayoum, Egypt. Irrigation and Drainage Systems. Kluwer, Dordrecht. Vol. 3 (2): 103-123.

[1]

[2]

Paper No 013. Presented at the 9th International Drainage Workshop, September $10-13,2003$, Utrecht, The Netherlands.

International Institute for Land Reclamation and Improvement (Alterra-ILRI), P.O. Box 47, 6700 AA Wageningen, The Netherlands, marinusgbos@cs.com

3] WaterWatch, Generaal Foulkesweg 28,

6703 BS Wageningen, The Netherlands, bastiaanssen@WaterWatch.nl 